\title{
The Effect of Using Innovative Furniture on Space Circulation in Lease Houses in Merauke
}

\author{
Muchlis Alahudin $^{1}$, Atizah Nurhusna ${ }^{2}$, Yosi Valentina Simorangkir ${ }^{3}$ \\ Architecture Department \\ Universitas Musamus \\ Merauke, Indonesia \\ ${ }^{1}$ muchlis@unmus.ac.id, ${ }^{2}$ atiza2nurhusna@gmail.com, ${ }^{3}$ yosisimorangkir90@gmail.com
}

\begin{abstract}
The thermal condition in lease houses in Merauke is very uncomfortable, one of the causes is that the existence of home furniture that are not well organized in many lease houses causes the circulation of space to be not smooth. With the condition of a narrow house with more and more needs, the need for furniture facilities is needed. If the selection and use of unwise furniture will affect the comfort of the building, the room will become full/crowded with the furniture. The purpose of this research is to design an innovative multi-functional furniture that has more than 4 functions in one piece of furniture. This study used an experimental method, the data analyzed included: the amount of each lease house, the amount of each room in the lease house, the amount of furniture and the amount of furniture, and this study focused on the bedroom. Innovative furniture designed to have more than 4 functions (multifunctional). Innovative furniture that is multifunctional in the bedroom can combine several types of furniture such as the bed, wardrobe, study desk, book cabinet, chair, and other functions. The space circulation becomes $45 \%$ for a spacious bedroom of $9 \mathrm{~m} 2$. Therefore, the circulation of space becomes better and the need for circulation based on the comfort of the physical movements of the occupants is fulfilled. In addition to better space circulation, thermal conditions (temperature, humidity, and air circulation) also get better.
\end{abstract}

Keywords - Innovative furniture; multifunctional

\section{INTRODUCTION}

House is one of the basic human needs which are included in the need of accommodation, it is needed to protect and to provide shelter to humans against external hazards such as weather (heat, wind, rain, etc.), dangerous animal attacks, and human crime. House is also an important factor in improving the welfare and quality of human life, furthermore the state in the power of the government and local government guarantees every citizen to be able to occupy and/or have a decent home in a safe, harmonious and orderly environment (Law No. 1 of 2011, Article 19 Paragraph 2).

In addition to functioning as a building that can provide safe and comfortable protection for its inhabitants, the house must also be able to accommodate basic human activities, including sleeping, eating, chatting, storing, cleaning the body, defecating, communicating, and socializing. Many housing developers/entrepreneurs set up rented residential houses (lease houses) to meet the housing needs. However, the lease houses that were built did not pay attention to the standards/provisions of a healthy house, housing developers are only oriented to profit for their business. In Merauke, the lease houses were built in an average building area of $48 \mathrm{~m}^{2}$ and below. In addition to the rented houses with small types, the environmental condition around the lease houses is also not well conceptual, the house ventilation is minimal and the number of series of rented houses built [1].

The thermal condition in lease houses in Merauke is very uncomfortable, one of the causes is that the existence of home furniture that is not well organized in many lease houses causes the circulation of space to be not smooth. With the condition of a narrow house with more and more needs, the need for furniture facilities is needed. If the selection and use of furniture are not wise, it will affect the comfort in the building, the house space will be full/crowded with furniture that is owned [2].

This study aims to create 1 (one) innovative furniture with a minimum of 4 functions (multi-function). In this study, the furniture is applied to the bedroom with a total capacity of 2 people. In addition, by creating an innovative multi-functional furniture design, it aims to increase the space circulation due to a large number of the need for furniture in the bedroom.

\section{LITERATURE REVIEW}

\section{A. Lease houses in Merauke}

The average area of rental housing per unit in Merauke is $48 \mathrm{~m}^{2}$, for furniture in the bedroom consists of the wardrobe, bed, study desk, and chairs while the occupants in the child's bedroom are on the average of 2 people. On 1 lot of lease houses, there are 4 rental housing units on the average. The recording and observing data of the building thermal condition in the rental housing are as follows [2]:

1. The effect of air temperature, from the results of the analysis of the temperature range in the building, is $29^{\circ} \mathrm{C}$ to $32^{\circ} \mathrm{C}$, while the average temperature outside the building is between $28^{\circ} \mathrm{C}$ to $31^{\circ} \mathrm{C}$, all in warm comfortable conditions until hot.

2. The effect of humidity, the average humidity inside and outside the building is around $72 \%$ to $80 \%$, and at $08.00-09.00$, the humidity reaches $80 \%$ which can be categorized in stuffy conditions after it decreases to less comfortable humidity at 10.00 - 16.00. One of the factors causing high humidity is the 
lack of openings and poor circulation of air. This is because of, among other things; poor ventilation and an excessive amount of furniture.

3. The air movement effect, the air velocity is very important in the effort to create a comfort value. When it was observed, the openings in the sample house are not fulfilling. The average wind speed in the building does not exceed 0.3 $\mathrm{m} / \mathrm{s}$ while the wind speed outside the building can reach 0.7 $\mathrm{m} / \mathrm{s}$. The orientation of the direction of the building that is not in line with the movement of the wind, the lack of vegetation of the dense placement of buildings and the lack of openings are the inhibiting factors of the entry of air flow into the house.

\section{B. Ergonomics}

Ergonomics is derived from the Greek word ergo which means work and nomos which means law. Ergonomics is intended as a systematic branch of knowledge to utilize information about the nature, abilities, and limitations of humans to design a working system so that people can live and work on the system properly [13].

Ergonomics, in general, is a branch of science that examines the nature, abilities, and limitations of humans in designing a working system to be effective, safe and comfortable. Ergonomics also provides an important role in improving work safety factors such as the design of a working system to reduce pain and aches in the human muscularskeletal system, the design of workstations for visual aids. This is done to reduce discomfort during work [13].

In general, the objectives of ergonomics implementation are: 1) Improving physical and mental well-being through efforts to prevent injuries and occupational diseases, reducing physical and mental workload, seeking promotion and job satisfaction. 2) Improving social welfare by improving the quality of social contacts, managing and coordinating work appropriately and increasing social security both during the productive age period and after being unproductive. 3) Creating a rational balance between various aspects, namely the technical, economic, anthropological and cultural aspects of each work system that is carried out so as to create a high quality of work and quality of life.

In summary, ergonomics can be defined as a branch of science that systematically utilizes information about the nature, abilities, and limitations of humans to design a system well [15].

\section{Spatial Planning Arranged Based on Its Purpose and Function}

To get a good composition of space, a unit of space is needed. This unity can be obtained with good arrangements and harmonious views4. The use of an arrangement must be in harmony with the demands of a harmonious and beautiful spatial arrangement. The composition of a space must be in accordance with its purpose, meaning that the use and arrangement of furniture is determined by the practical needs and life habits of its inhabitants. Furniture that is used to achieve the same goal is united into one function group. The function units must still be well regulated, so that circulation space is still available. So we must note that the grouping of furniture according to its function is the basis for compiling space with good circulation. The concrete example is in the preparation of furniture for the waiting room for visitors, furniture for guest chairs and tables that have the same function to be made in one collection so as not to interfere with the circulation of space formed [8] [14].

In the lease houses in Merauke, in the bedroom there are some items of furniture in it; 1). Bed, 2). Wardrobe, 3). Study Desk, 4). Chairs and occupied by 2 people with total furniture area of $7.26 \mathrm{~m}^{2}$, with a space of $9 \mathrm{~m}^{2}$ only has a circulation of $20 \%$. With innovative furniture in the next bedroom only contains furniture: 1). Bed, 2). Multifunction cabinets and occupants of 2 people, the area of space circulation increased by $15 \%$ in total area to $35 \%$. With a circulation of $35 \%$ of physical comfort needs, this circulation is good for the room used by two residents. The application of innovative furniture can be seen in table 1 [1]

TABLE I. SPACE SizE AfTER INNOVATIVE FuRNITURE IS IN THE RoOM

\begin{tabular}{|l|l|l|l|l|l|}
\hline $\begin{array}{c}\text { Type of } \\
\text { Room }\end{array}$ & $\begin{array}{c}\text { Types of } \\
\text { Furniture }\end{array}$ & $\begin{array}{c}\text { Length } \\
(\mathbf{m})\end{array}$ & $\begin{array}{c}\text { Width } \\
(\mathbf{m})\end{array}$ & Amount & $\begin{array}{c}\text { Total } \\
\left(\mathbf{m}^{\mathbf{2}}\right)\end{array}$ \\
\hline \multirow{5}{*}{ Bedroom } & Bed & 2.16 & 1.36 & 1 & 2.9376 \\
\cline { 2 - 6 } & $\begin{array}{l}\text { Multi- } \\
\text { function } \\
\text { Wardrobe }\end{array}$ & 1.2 & 0.4 & 1 & 0.48 \\
\cline { 2 - 6 } & Humans & 1.2 & & 2 & 2.4 \\
\cline { 2 - 6 } & Total Area & & & $\mathbf{5 . 8 2}$ \\
\hline
\end{tabular}

\section{RESEARCH METHOD}

In this study, the experimental method was conducted, the data analyzed included: amount of each lease house, the amount of each room in the lease house, the dimension of furniture and the amount of furniture, the study focused on the bedroom. Innovative furniture designed to have more than 4 functions (multifunctional). Furniture testing is carried out in the Department of Architecture, Universitas Musamus, Merauke.

\section{RESULTS AND DISCUSSION}

With the results of the study, 1 piece of innovative furniture has 6 functions, including bed, study desk, wardrobe, bookcase, and table that can be used for other activities (ironing table, etc.). This innovative furniture plan is to be used for 2 people in the bedroom.

TABLE II. SPACE SizE With MultifunCtional InNOVATIVE

\begin{tabular}{|c|l|l|l|l|l|}
\hline $\begin{array}{c}\text { Type of } \\
\text { Room }\end{array}$ & $\begin{array}{c}\text { Types of } \\
\text { Furniture }\end{array}$ & $\begin{array}{c}\text { Length } \\
(\mathbf{m})\end{array}$ & $\begin{array}{c}\text { Width } \\
(\mathbf{m})\end{array}$ & Amount & $\begin{array}{c}\text { Total } \\
\left(\mathbf{m}^{2}\right)\end{array}$ \\
\hline Bedroom & $\begin{array}{l}\text { Innovative } \\
\text { furniture } \\
\text { (Bed, } \\
\text { Wardrobe, } \\
\text { Study } \\
\text { desk, } \\
\text { Bookcase, }\end{array}$ & 2.8 & 0.9 & 1 & 2.52 \\
\hline
\end{tabular}




\begin{tabular}{|l|l|l|l|l|l|}
\hline $\begin{array}{c}\text { Type of } \\
\text { Room }\end{array}$ & $\begin{array}{c}\text { Types of } \\
\text { Furniture }\end{array}$ & $\begin{array}{c}\text { Length } \\
(\mathbf{m})\end{array}$ & $\begin{array}{c}\text { Width } \\
(\mathbf{m})\end{array}$ & Amount & $\begin{array}{c}\text { Total } \\
\left(\mathbf{m}^{2}\right)\end{array}$ \\
\hline \multirow{2}{*}{$\begin{array}{c}\text { Chairs, } \\
\text { wardrobe) }\end{array}$} & & & & \\
\cline { 2 - 6 } & Humans & 1.2 & 1 & 2 & 2.4 \\
\cline { 2 - 6 } & Total Space & & $\mathbf{5}$ \\
\hline
\end{tabular}

The total area of bedroom furniture $=5 \mathrm{~m}^{2}$, using innovative furniture/multi-function circulation in the room $9 \mathrm{~m}^{2}$ to $45 \%$, according to the standard circulation of $45 \%$ circulation and physical comfort (body movement), this circulation is good for the room used for two occupants.
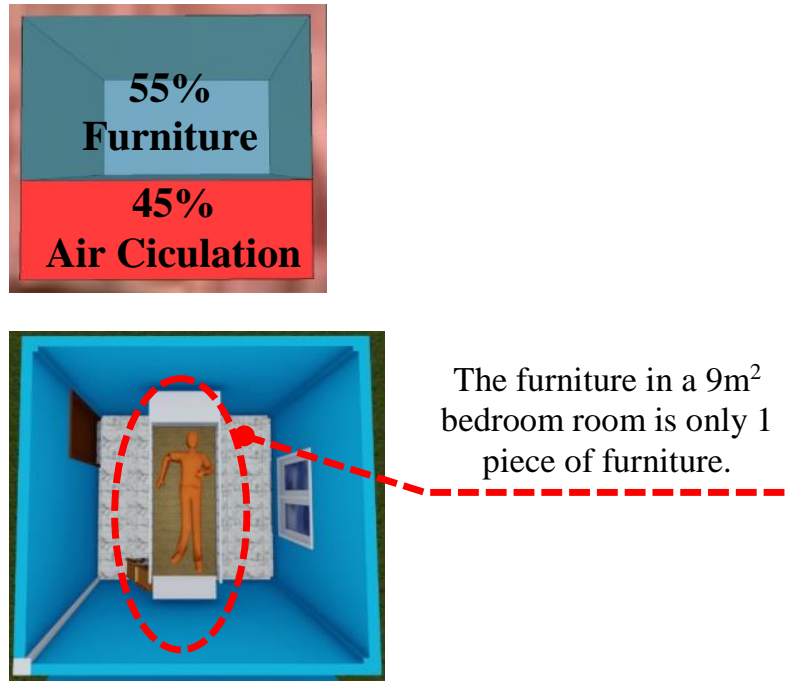

Fig. 1. The air circulation of room space after multi-functional Innovative Furniture and Furniture Design Results

The innovative furniture which is also a multi-functional furniture, from previous research in 1 room (bedroom room) there are some furniture needs, including: bed, wardrobe, study desk, and chair. Because the bedroom is occupied by 2 people, the bed used is a double bed as the room is narrow. In this study, one piece of furniture is designed that can combine several items of furniture, including: bed, wardrobe, study desk, bookcase and chair.
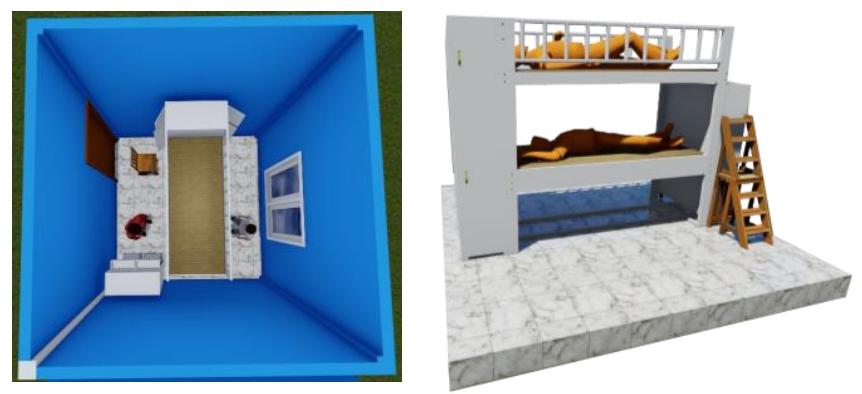

Fig. 2. Installation of the innovative furniture in a room space of $9 \mathrm{~m} 2$
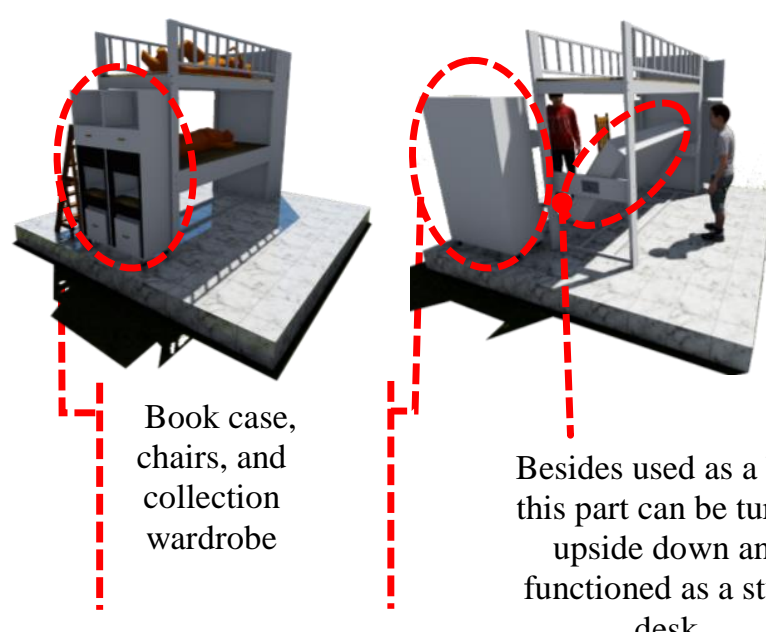

Besides used as a bed, this part can be turned upside down and functioned as a study desk.

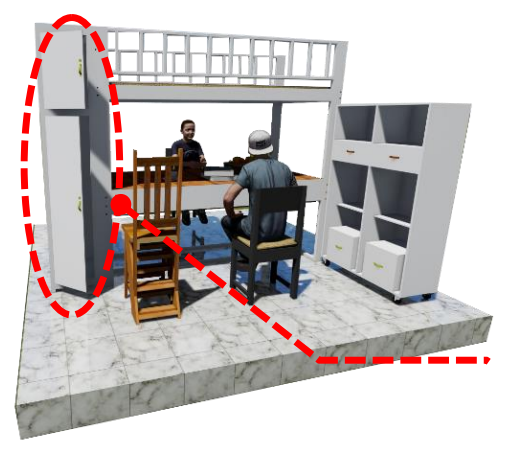

Wardrobe. For 2 users. 2 sides divided; left side and right side cabinets.

Fig. 3. The Functions of each item of innovative furnitue

\section{CONCLUSIONS}

From the research process and the design of innovative furniture for lease houses in Merauke, it can be concluded as in the following:

1. By using innovative furniture that is multifunctional, in the bedroom room there is only 1 furniture with several functions as the bed, wardrobe, study desk, bookcase, chairs, and other functions. Space circulation becomes $45 \%$ for a spacious $9 \mathrm{~m}^{2}$ bedroom, so that the circulation of space becomes better, the need for circulation based on the physical comfort of the occupants is fulfilled. In addition to better space circulation, the thermal conditions (temperature, humidity, and air circulation) get better.

2. With this multifunctional innovative furniture, the privacy of the 2 occupants of the room gets better.

\section{ACKNOWLEDGMENT}

Acknowledgements given Kemenristekdikti which has provided grants PPT SIMLITABMAS 2016 to the researcher, the University Musamus, especially LPPM which has provided support for the study as well as to other parties who participated during the study, contributed to the publication of the article. Thanks are also given to the Department Architecture, Universitas Musamus Merauke, which has been providing support to research activities. 


\section{REFERENCES}

[1] A. Muchlis, T. Anton, L. Martha, "Innovative Furniture Design for Lease House Occupant in Merauke,” ICOVET Advances in Soc. Sci. Educ. and Humanit. Res., vol. 116, 2017.

[2] Alahudin, M. Jayadi, "Surrounding Environmental Conditions Against Thermal Comfort of Rental Houses (A Case Study of Rent Houses in Seringgu Jaya Merauke Sub-District)," Mustek Anim Ha, Vol. 3 no. 1 April, 2014.

[3] Frick, Heinz, Simple House, Yogyakarta: Kanisius, 1986

[4] J. Panero, and Z. Martin, Human Dimension \& Interior Space, London: The Architectural Press, 1979.

[5] Decree of the Minister of Settlement and Regional Infrastructure of Indonesia Number 403/KPTS/2002 concerning Healthy Simple Houses, 2002.

[6] K.M. Gani, The Right Designing Technique, Yogyakarta: Kanisius, 1993.

[7] C.P. Kukreja, Tropical Architecture, New York: Tata Mc. GrawHill Book Publishing co.Limited, 1978.

[8] M.S. Indraswara, "Study of Furniture Placement and Color Usage (Case Study in the Bedroom of Bandungan-Ambarawa Tourism Nugraha Hotel)", Enclos. J. Ilm. Peranc. Kota dan Permukim., Vol. 6 No. 1., March 2007.

[9] M.S. Suryo, "Analysis of Minimum Area Needs in Simple Sites in Indonesia”, J. Permukim., Vol. 12 No. 2, pp. 116-123, November 2017. $116-123,2017$.

[10] E.S. Marizar, Furniture Designing Techniques for Designing Creative Furniture (Conception, solutions, innovation, and implementation), Yogyakarta: Media Pressindo, 2005.

[11] E. Neufert, Architect Data, Vol. 1, Jakarta: Erlangga, 1996.

[12] E. Neufert, Architect Data, Vol. 2, Jakarta: Erlangga, 1996.

[13] N. Eko, Basic Concept Ergonomics and Its Application, Surabaya: Guna Widya, 2008.

[14] Law No. 1 of 2011 about Housing and Settlement Areas.

[15] S. Tarwaka and L. Sudiajeng, Ergonomics for Safety, Occupational Health and Productivity, Surakarta: UNIBA PRESS, 2004. 